\title{
Glass Structures in Post-Industrial Buildings and the Role of the Industrial Heritage in Shaping Creative Urban Spaces
}

\author{
Anna Sulimowska-Ociepka \\ Faculty of Architecture, Silesian University of Technology, Gliwice, Poland
}

Received October 22, 2020; Revised January 16, 2021; Accepted February 17, 2021

\section{Cite This Paper in the following Citation Styles}

(a): [1] Anna Sulimowska-Ociepka, "Glass Structures in Post-Industrial Buildings and the Role of the Industrial Heritage in Shaping Creative Urban Spaces," Civil Engineering and Architecture, Vol. 9, No. 2, pp. 281 - 292, 2021. DOI: 10.13189/cea.2021.090202.

(b): Anna Sulimowska-Ociepka (2021). Glass Structures in Post-Industrial Buildings and the Role of the Industrial Heritage in Shaping Creative Urban Spaces. Civil Engineering and Architecture, 9(2), 281 - 292. DOI: 10.13189/cea.2021.090202.

Copyright $\odot 2021$ by authors, all rights reserved. Authors agree that this article remains permanently open access under the terms of the Creative Commons Attribution License 4.0 International License

\begin{abstract}
This paper presents the topic of postindustrial structures as crucial elements shaping the image of contemporary cities and it demonstrates their value against the background of the evolution of the concept of the industrial culture heritage. Irrespective of their scale and initial intended use, postindustrial structures constitute an important trace of the tradition and culture of a given place. They are often crucial elements of the cultural landscape and landmarks for subsequent generations of local communities. More and more frequently, cities notice their potential, based on which they can build their own attractive image. Contemporary technology and technique offer numerous possibilities of making use of this heritage in order to create urban space of a new quality and exhibit surprising aesthetic values. One of such possibilities is a creative application of glass - a material which offers nearly limitless possibilities of creating an architectural form. Based on in situ studies and literature research, the paper presents examples illustrating how thanks to the application of advanced glass structures buildings which have already lost their original functions get re-discovered for the cultural landscape of the city and co-create its new quality.
\end{abstract}

Keywords Industrial Heritage, Adaptive Reuse, Glass Structure, Smart City

\section{Introduction - Origins of the Problem}

Contemporary cities are full of relics from the past, testifying to their history and culture. Cities whose image is a result of centuries and of historical events that accompanied them delight us with their beauty and unique identity. Each of their historic buildings is a testimony to their rich history and constitutes an important element of their cultural heritage. The cultural landscape of these cities, besides structures which are commonly recognised as valuable and appreciated by specialists: art historians, monument conservators, culture experts, comprises also structures whose history is not that distant and which we often do not notice on the daily basis. It is difficult to associate them with memorable historical events, and yet it is thanks to them that over the last 200 years the world experienced civilisation progress never encountered before, and the centuries-long concept of building cities changed completely. It is often difficult to notice stunning beauty in them as they were not designed to be beautiful. Industrial structures, as this is all about them, were to be used for the purposes of production and narrowly understood economics of industry. During the initial period of industrialisation their creators included constructors, mechanics, and metallurgists - pioneers of the emerging technical intelligence. Inspired by growing functional and spatial requirements, as well as by new 
materials - first cast iron, a bit later reinforced concrete, they created structures which were not burdened with the traditional thinking about the architectural form. However, only the beginning of the $19^{\text {th }}$ century and the immense fascination with machines visible in the works of the avant-garde of the 1920s brought changes thanks to which industrial buildings became interesting to progressive architects. Such designers as Behrens, Gropius, Poelzig, and Mendelson, representing different aesthetic approaches, defined new principles for architectural shaping of industrial structures, and their works are regarded as ground-breaking. [1]. They are accompanied, however, by countless industrial structures designed by anonymous designers, which do not stand out with their form and incorporate no revolutionary structural solutions. For years they humbly served production technology, water and energy supply, provided and organised transport, storage, and supported the extraction of raw materials. Having no unique features besides their scale, they provided jobs and facilitated the lives of city dwellers, becoming inseparable from their cultural landscape. When, however, they lost their functions as a result of technological changes, and they turned out to be dispensable, which usually lead to thoughtless liquidation. Many valuable postindustrial buildings were destroyed in the process, even though they had managed to become elements of the city landscape and constituted an important symbol of identity for local communities. As Niel Cossons [2] aptly put it, "The industrial heritage is of wider social and cultural significance as part of the record of people's lives, and as such provides an important sense of history and identity. In many cases industrial areas have been liquidated by years of deindustrialisation, and industrial communities connected with them have been marginalised [3]. Responsibility for their protection rests on the shoulders of municipal authorities, artistic circles, and local communities. It is their sensitivity to the hidden beauty and their awareness of the development potential that the survival of postindustrial structures depends on. The value of the cultural capital of postindustrial heritage as a local development factor has been recognised and appreciated by experts from different fields. Practice shows that including historical industrial buildings in revitalisation projects may become a catalyst of changes, and at the same time - combined with the involvement of local communities - it enables sustainable development in the process of designing creative urban spaces. They attract the creative class, which - as Richard Florida [4] puts it - constitutes the contemporary driving force of economic development and constitutes a magnet for subsequent investments.

\section{Methodology and Objective of the Study}

The study is divided into two parts. The first part is based on a comparative analysis of literature devoted to cultural heritage and industrial heritage. This allowed to investigate the evolution of the meaning of the term 'cultural heritage' and set revitalisation measures in the theoretical context. The said analysis shows the direction that will be followed by contemporary measures focusing on the renovation of historical postindustrial structures, set in the context of local development and cultural heritage marketing. The second part of the study is based on an analysis of examples of renewals and adaptive reuses of historical postindustrial buildings. This part of the research, based on in situ studies and on the analysis of literature, focused on structures which shared a similar history and location in port cities in degraded shipyard and port zones within the area of waterfronts. Their shared origins and activities undertaken in order to include postindustrial areas in the functioning zone of the city demonstrate the value of the industrial heritage for creating a new quality of urban space. The subject matter of a detailed analysis are glass structures added to historic buildings. This analysis refers to constructional solutions, material solutions, and visual effects which have been thus achieved. It was performed on the basis of field studies and an analysis of reference materials. The objective of this paper is to organise the knowledge on the evolution of the terms 'cultural heritage' and 'industrial heritage', as well as to provide examples illustrating changes in heritage philosophy. Furthermore, the paper demonstrates the possibilities of applying glass structures exhibiting different degrees of complexity in the process of adapting postindustrial buildings and their effect on designing a creative space of contemporary cities and metropolises.

\section{Literature Review - Evolution of the Terms 'Cultural Heritage' and 'Industrial Heritage'}

The term 'cultural heritage' undergoes constant changes along with the processes that take place in science and in the contemporary world. The doubts evoked in the 1980s by the postmodern philosophy in the scientific concepts used until then released some space for a new interpretation of historically established meanings. A wide discourse, which has been present in the scientific circles since the end of the $20^{\text {th }}$ century, is responsible for involving such experts as monument conservators, art historians, culture experts, ethnographers, but also architects, economists, and politicians in the topic of heritage. Nowadays, an interdisciplinary approach to this issue offers many parallel interpretations and concepts which expand the term 'cultural heritage'.

Before the mid- $20^{\text {th }}$ century, heritage used to be identified with monuments, which was interpreted based on conservation doctrines from the turn of the $19^{\text {th }}$ century, 
associated with such figures as Alois Frodl, Max Dvorak, and Georg Dehio. This period was summarised in the provisions of the Athens Charter of 1931. In the mid-20 ${ }^{\text {th }}$ century exclusively material structures exhibiting certain historical, artistic, or scientific values were regarded as heritage. At the same time, there was a time when the term 'monument', too narrow to fully describe the richness of tangible and intangible values, started to be gradually replaced with the term 'cultural assets' (beni culturali). The 1970s saw a slight increase caused by a different distribution of emphasis, consisting in considering monuments along with their spatial and historical context. This change was caused by the provisions of the Venice Charter of 1964, which remained a valid conservation doctrine for a long time.

The breakthrough, based on the postmodernist philosophy, took place in the 1980s, when a broad academic discussion went beyond the area of monument conservation and cultural heritage became an interdisciplinary concept. Consequently, heritage encompasses everything from the past that deserves protection and being handed down to subsequent generations [5]. John Turnbridge [6] writes: “.... since the 1970s the fate of this concept has been intertwined with other current debates, for example on environmental protection, diversification of traditional lifestyles, or promotion of images of places which could be given a common name spostmodernism>- which in turn relates to such values as applying human standards and separate local identities. ...Currently, this concept is used not only to refer to the historical environment - the natural one as well as the one built by a human hand - but also in the context of all manifestations of material and intellectual legacy and cultural identities." This approach was established by the Faro Convention from 2005, which equated tangible and intangible heritage, made the heritage of local communities as important as the national heritage, and regarded the landscape as important as the artefact. Pierre Nora [7] observes that heritage, "which until recently was still based on a selection of the oldest, the most beautiful, and the most perfect products of 〈national genius〉, currently has ended the epoch of history, nation, and monuments in favour of the epoch of memory, community, and identity".

Such a balanced approach clashes with a radical view of Gregory Ashworth [8], who perceives heritage as a process of creating a certain image of the past in the present by means of selected and accepted artefacts, memories, and history. In such an approach the objective of heritage is the contemporary consumption of the past, from which relevant elements are selected and interpreted, taking into account measurable social, economic, and political benefits. He believes that for this reason heritage can become an effective tool of the urban policy.

As Krzysztof Kowalski [5] writes, "the axis of studies on heritage is not a reflection on the past as such, but contemplation of present, social strategies of constructing, interpreting, using, and managing it on different intermingling levels." This interpretation makes a reference to contemporary theories of economics and marketing of heritage. Nowadays, conservation theories focusing exclusively on the protection of historic values, do not fully address the currently emerging issues associated with the contemporary methods of making use of heritage. With reference to the universally understood concept of cultural heritage in the tangible as well as intangible sphere, new criteria appear, connected with the need to manage heritage resources. They incline to consider heritage also in social and economic categories. Such an approach is presented in the most up-to-date studies of researchers in the field of heritage economics and marketing.

Ruth Towse [9] argues that in special cases the cultural heritage can be regarded as multi-product enterprises, which produce a combination of complementary services for visitors (e.g., an exhibition, education, catering, trade) and internal services (conservation, expert, research services), which are subject to general principles of economics. David Thorsby [10] proves that between culture, including cultural heritage, and economic processes there can be interdependencies within the economic environment, the simplest example of which is the production and consumption of cultural assets, which are characterised by purely economic processes. The topic of heritage economics is undertaken by - among others Jacek Purchla [11], who points to many economic aspects, pertaining to such issues as tourism development, resources facilitating development and improving the quality of life, creating the job market, as well as image building resources. As Monika Kupisz-Murzyn [12] argues, the cultural heritage considered in such categories becomes a subject of a market game and is subject to similar conditions. In this context a possibility of making use of industrial heritage resources emerges, focusing on postindustrial structures which have lost their original economic function, and due to their location, often in central zones, they become a spatial barrier for further development of the city. The industrial heritage, however, was not appreciated straight away.

\subsection{Development of the Term 'Industrial Heritage'}

The first manifestations of interest in historical industrial structures appeared in England in the 1950s. This is then that the term 'industrial archaeology' was coined with reference to a science interested in manifestations of human activities in terms of technical progress and workplace environment, stemming from the English industrial revolution [13] [14]. Only during the TICCIH Congress in Stockholm in 1978, this concept got separated from the $18^{\text {th }}$-century industrial revolution and it 
was decided that the subject matter of industrial archaeology comprises also the social phenomena and tangible evidence of industrialisation, as well as its heritage crucial for the present day. Thus, it was acknowledged that the scope of industrial heritage comprises the epoch of human activity relating to the entire industrialisation process. The first international document in which industrial heritage was recognised as worthy of protection is the Burra Charter of 1979, which sets forth that places of cultural importance can alco include postindustrial areas.

The industrial culture heritage was included, therefore, in the area of interest of art historians, monument conservators, culture experts, and architects relatively late - only at the end of the 1970s, when a considerable part of historical industrial buildings had been already destroyed or liquidated. The change in their perception and protection method was associated with the period of economic transformation and restructuring of the traditional industry in Western European countries, which were established by waves of postmodernist ideas. Beauty, authenticity, and a unique cultural value were noticed in production facilities then. Today such an approach comes as no surprise, but many years of experience were necessary to recognise the industrial culture as a part of the European cultural heritage and to admit it needed similar protection, too.

Nowadays, the industrial heritage understood as a record of the history of technical civilisation of humanity is recognised as a part of universally understood cultural heritage. Many definitions have emerged around this concept, the most important of which seems to be the one included by TICCIH in the Nizhny Tagil Charter for the Industrial Heritage of 2003 [15]. It provides that the industrial heritage consists of the remains of industrial culture which are of historical, technological, social, architectural or scientific values. These remains consist of buildings and machinery, workshops, mills and factories, mines and sites for processing and refining, warehouses and stores, places where energy is generated, transmitted and used, transport and all its infrastructure, as well as places used for social activities related to industry, such as housing, religious worship, or education. The Nizhny Tagil Charter provided the grounds for the most important international doctrinal document devoted to the protection of industrial heritage - the so-called Dublin Principles, i.e., common guidelines of ICOMOS - TICCIH in terms of conservation of buildings, structures, areas, and landscapes of industrial heritage, adopted in 2011 at the $17^{\text {th }}$ ICOMOS General Assembly in Paris. The consequence of this still faint awareness of the value of industrial heritage is the European Strategy for Promotion of Industrial Heritage, adopted in Genk in 2014. Its provisions try to strengthen the cultural significance and economic potential of industrial heritage.

\section{Potential of Postindustrial Areas and Structures in Port Cities}

The deindustrialisation process and the process of revitalisation of postindustrial areas that followed are particularly well visible in cities whose economy was based on an industrial monoculture. Vast areas degraded by industry and socioeconomic phenomena that accompanied the process of industry restructuring generated crisis situations. Such problems can be observed in historical agglomerations of the traditional raw materials industry, textile industry, as well as in port cities, which for hundreds of years were developing based on the maritime trade and the shipbuilding industry.

Starting from the 1960s traditional ports located in inner cities were not able to keep up with rapid changes associated with a rise in the scale of ships and the unloading and warehousing methods. Huge container ships became a dominant form of maritime transport, which was related to the need to enlarge and deepen port pools. Methods of goods reloading changed, as well from small-scale pallets, boxes, or bags to container transport requiring specialist equipment and qualified technical staff. Historical port areas turned out to be too small for enormous cranes and reloading appliances and there was a need to organise vast warehousing areas with a well-developed logistic services zone [16]. A similar situation affected the European shipbuilding industry, which was considerably reduced as production was moved to Far East countries. Consequently, areas which had been occupied by the maritime industry and transport gradually got abandoned. Most often located in inner cities, on the one hand they were becoming a spatial barrier for harmonious development, and on the other - potential investment territories for countless investments for which it was difficult to find the right place in the dense urban structure of historical port cities. The released spaces became, therefore, an excellent place for creating new urban spaces, often commercial throughout, but also a test site for verifying non-standard architectural solutions. Even though initially the most characteristic spatial elements reminding of the history of these places, such as cranes, gantries, silos, were the first to disappear from the landscape of ports and shipyards, as the value and potential of the industrial cultural heritage became more appreciated, more and more examples of their preservation and adaptation for other purposes can be encountered.

\subsection{The Culture Yard - Helsingør, Denmark}

An excellent example of transforming a territory of a shipyard and incorporating it in the urban structure of the city is Helsingør, Denmark. Liquidation of one of the biggest Danish shipyards in 1982 forced the local authorities to redefine the directions of further 
development. At the same time, it created a unique opportunity to strengthen the cultural character of the city, within the perimeter of which there is one of the biggest tourist attractions in Denmark - the castle and fortress of Kronborg. The superior goal of the revitalisation measures commenced in Helsingør at the turn of the $20^{\text {th }}$ century was, therefore, to incorporate the previously isolated territory of the shipyard in the urban structure of the city, and in doing so providing a cohesive urban complex that would link the castle of Kronborg located on the outskirts of the city with the historical city centre and the ferry quay situated on the other side of the shipyard pool. The new urban complex located within the perimeter of the historical shipyard was dubbed Culture Harbour Kronborg [17].

The most characteristic structure of the Culture Harbour is the Culture Yard, which was created in historical offices and warehouses of the former shipyard. In 2014 an architectural competition was announced, won by the AART Architects studio from Aarhus. The winning design, in compliance with the competition rules planned to transform the existing warehouses into a multifunctional culture centre, which on the surface area of ca. 13 thousand square metres would house such venues as a library, concert halls, conference and exhibition spaces, as well as a shipyard museum and catering facilities [18].

The historic brick buildings were enveloped in a dynamic, faceted glass structure, which emphasises the entrance zone and closes the representational piazza opening up towards the sea (Figure 1). The light glass structure added to the existing three-floor buildings was inspired by the shape of sails filled with wind. The seemingly complicated geometry of the glass envelope was obtained thanks to the multiplication of less complex shapes of individual elements. A simple, steel framework with the height reaching three floors rests on the historical buildings and serves as a support, to which a spatial steel frame consisting of triangular elements is fastened. This substructure constitutes a repetitive element, which covered with panels of selective low-E glass - creates a multidimensional structure linking individual buildings and housing an entrance zone and a part of the library open towards a mezzanine (Figure 2). The thoughtful geometry of the envelope allows to make optimum use of daylight entering the building, and the use of openwork aluminium panels reduces the process of overheating of the interiors from noon on. This sophisticated structure, proposed by Søren Jensen Consulting Engineers, in 2011 received the Structural Award granted by the British Institution of Civil Engineers.

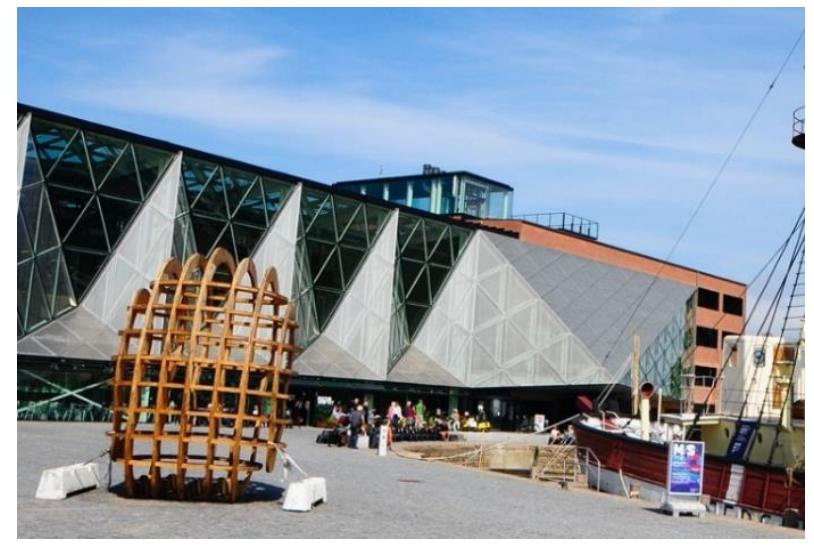

source: photo by the Author

Figure 1. Culture Yard in Helsing $\varnothing \mathrm{r}-$ a glass structure surrounding the complex of historical buildings housing offices and warehouses of the former shipyard.

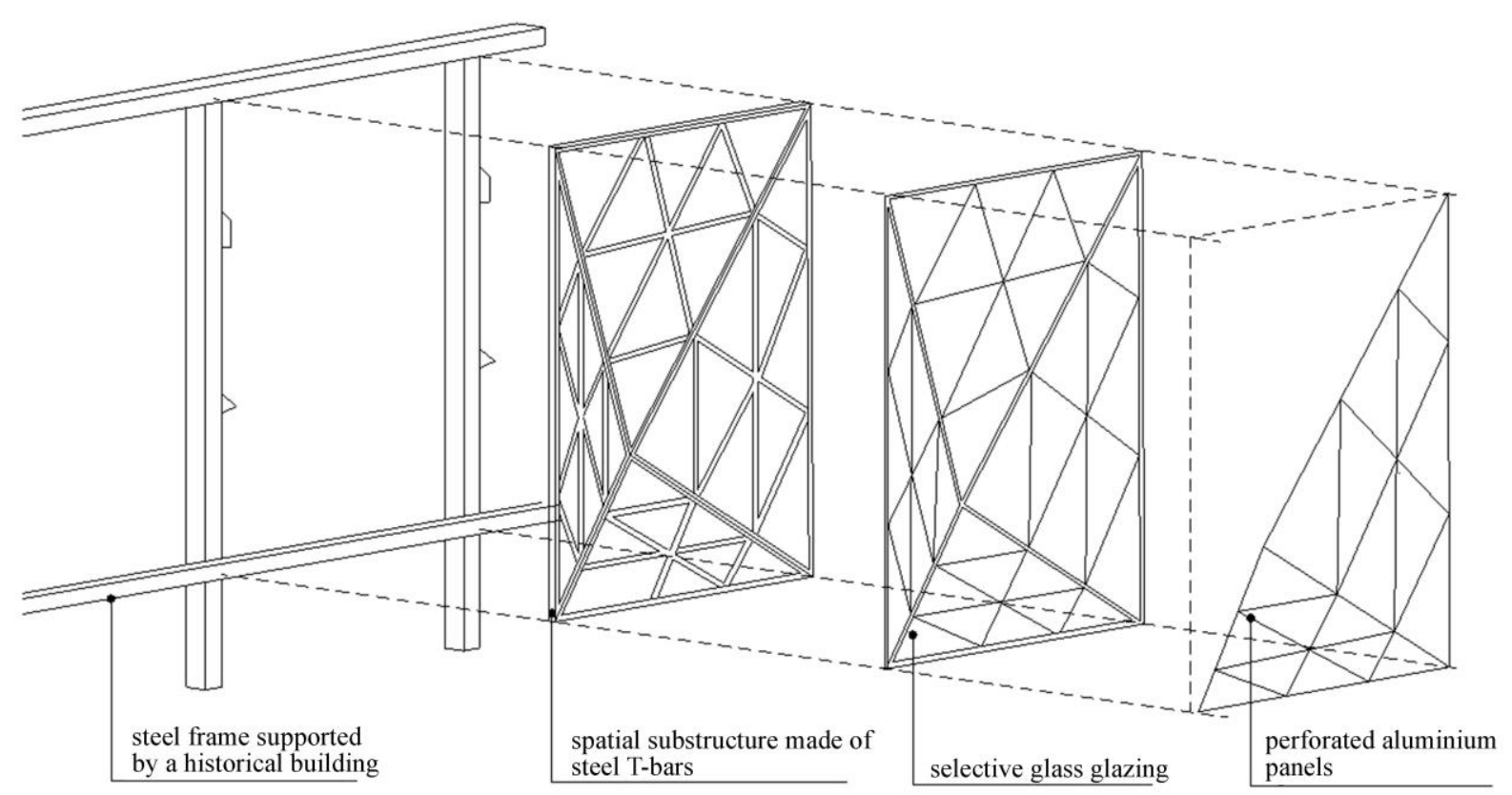

source: drawing by the Author based on drawings by Søren Jensen Consulting Engineers

Figure 2. Diagram of designing the multidimensional glass structure 


\subsection{MOCAA - Museum in Cape Town, South Africa}

A similar faceted glass structure, although much smaller in scale, accompanying an adaptation of a building of a former industrial infrastructure, appeared in Cape Town in South Africa. Contrary to Helsingør, this investment was not to constitute a stimulus for the development of a postindustrial zone. Instead, it was only to complement the already functioning commercial zone with a cultural facility. In 2014 it was decided that an enormous Grain Silo Complex, located in the centre of the revitalised territory of the port waterfront, would be transformed into a museum of the contemporary African art. MOCAA - Museum of Contemporary African Art designed in 2016 by a London-based designing studio Heatherwick, became the first museum of this scale and rank in Africa. Its monolithic, reinforced concrete body, erected in 1927, 57 metres high, consisting of 42 silos arranged one next to another, presented a significant difficulty in the context of the planned museum function. Since it was the investor's plan to maintain the original historical form as fully as possible, the greatest challenge was how to organise the exhibition space in the compact system of reinforced concrete silos - tubes with the diameter of $5.5 \mathrm{~m}$ and height of $30 \mathrm{~m}$. This challenge, addressed creatively by designers, brought a spectacular effect inside. From the outside the edifice did not change its appearance and it still exudes the austere beauty of concrete. However, thanks to a central elliptical atrium hollowed out in the compact system of the silos, a sculptural, multidimensional interior was created. The revealed organic space of the concrete cylinders is permeated by beams of light introduced by the glazed roof. The upper levels, located above the silos, were adapted for the purposes of a museum café, an outside terrace with a collection of statues, and a luxury hotel [19].

The surprising and brutal beauty of the space inside is hidden behind an original reinforced concrete façade, free from any intervention. The only outside trace which reveals the transformation inside are the glass faceted structures, filling the mesh of the reinforced concrete framework hovering above the silos. The initial brickwork in this place was replaced with multi-wall panels of the dimensions of ca. $5 \mathrm{~m} \mathrm{x} 6 \mathrm{~m}$ at the stage of functional transformations. The spatial glass structures consisting of 56 triangular panels of double construction glass are embedded in steel frames fixed directly on the reinforced concrete mesh. 1m-deep cushions were created this way (Figure 3). Thanks to the application of high transparency and high reflectance glazing, during the day they reflect textures and ever-changing colours of the sky. The glass reflectance phenomenon was strengthened in this case by means of multiple refraction of planes of the glazing and a big contrast between the intensity of light outside and inside [20]. The unique and surprising visual effect did not need the application of any special technology and is only a result of complex geometry and creative use of the simplest materials. 


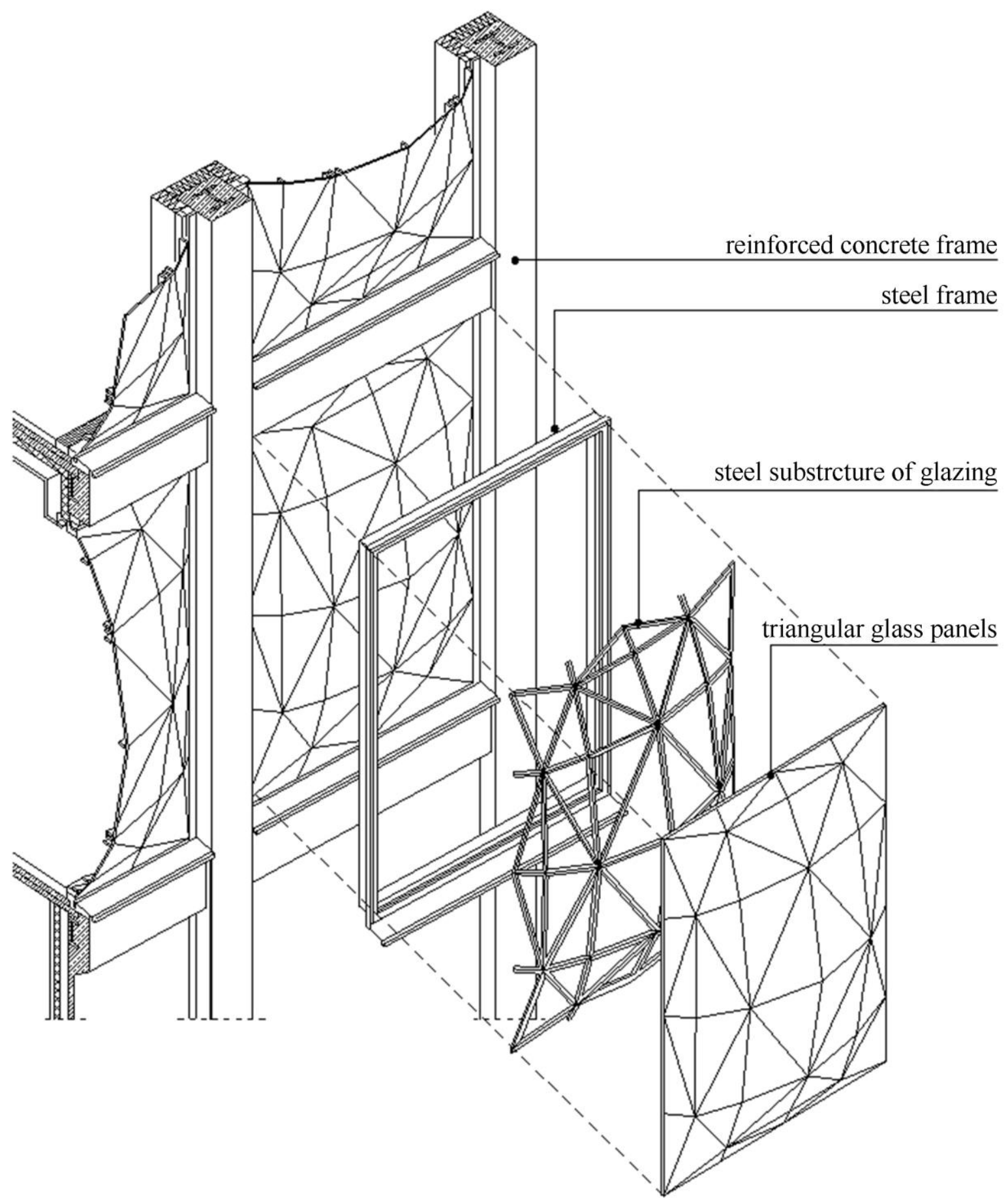

Source: drawing by the Author on the basis of www.heatherwick.com/project/zeitz-mocaa/

Figure 3. Diagram of the spatial structure of the glazing in the mesh of the original reinforced concrete structure.

\subsection{Rockheim Museum - Trondheim, Norway}

A grain warehouse also became a subject of an architectural intervention in Trondheim in Norway. The idea of transforming the warehouse into a National Rock and Pop Museum appeared in 2005 and was associated with the need to refresh the image of an abandoned space of the industrial and port district of Brattora and to incorporate it in the spatial structure of the city. The terms and conditions of the architectural competition announced by the Ministry of Culture in Norway read that the historically valuable building of the port warehouse from 1920 should be preserved as fully as possible, with the most extravagant concept of adaptation and extension, which should make a reference to the expressiveness of rock music. At the same time, the functional programme 
proposed for the museum required that the floor area should be doubled with no possibility of extending the building in the field. The winning concept by the Pir II studio proposed adding a superstructure to the historical buildings, an independent cuboidal element housing an exhibition hall, and a small cube at the level of the ground floor housing a concert hall.

The concept of the exposition planned to create a fully interactive exhibition space, where the history of the Norwegian rock and pop music was presented, starting from the 1950s. The historical building of a reinforced concrete frame structure houses an atrium leading visitors to higher floors and museum staff premises. Both inside and outside, it was the designers' intention to confront the historical building with modern forms and materials. Glass stairs leading to upper floors and interactive installations contrast with the austere beauty of the reinforced concrete of the building frame. The cuboid glass body suspended above the historical warehouse was cut off from the historical elevation of the warehouse with a neutral, withdrawn glazing. The two-floor superstructure is separated from the historical building with a level of a view platform and a cafe, the glass floor of which, enabling to take a peek inside the building, allows history and modernity to intermingle. What is hugely impressive, however, is the façade of the new structure, which is covered with 420 square glass panels with prints of covers of rock music albums, suggestive of the subject matter of the museum exposition (Figure 4). The digitally printed glazing, thanks to the application of ceramic paint and additional lamination, is resistant to unfavourable atmospheric conditions present in the harsh coastal climate of Northern Europe and to the UV radiation. The mosaic of monochromatic reproductions of music albums covers 800 square metres of the glazed surface and constitutes a collage in quite an impressive scale. Thanks to the application of white print, it does not dominate the historical building and it constitutes a semi-translucent decorative layer, which on the one hand limits the translucency of the glass structure, and on the other fulfils a narrative function, making a reference to the intended use of the building [20]. A certain problem could be a low degree of privacy offered by the architectural detail of the media-façade due to the degree of transparency of glass panels. It can weaken a positive perception of the architectural solution observed close up in daylight. [21] The building comes to life only at night, when the glass structure is illuminated with a system of 14 thousand individually controlled LEDs. The interactive technology applied, the so-called media façade, allows to display changing static and dynamic coloured images, which can be controlled and generated by users of the public space around the building by means of mobile apps (Figure 5). Thanks to the pulsating colourful illumination, the impressive facade illuminates the night sky, giving an impression of the northern lights hovering above a fjord.
Thanks to the application of advanced technologies, it skilfully creates an astonishing visual effect, which highlights the character of the building and builds a completely new image and atmosphere of this place after dark [22] [23].

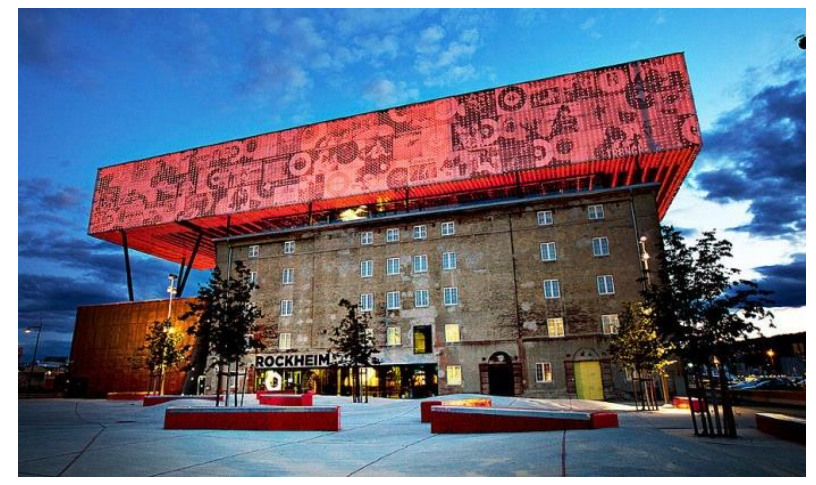

Figure 4. Rockheim Museum, Trondheim, night illumination

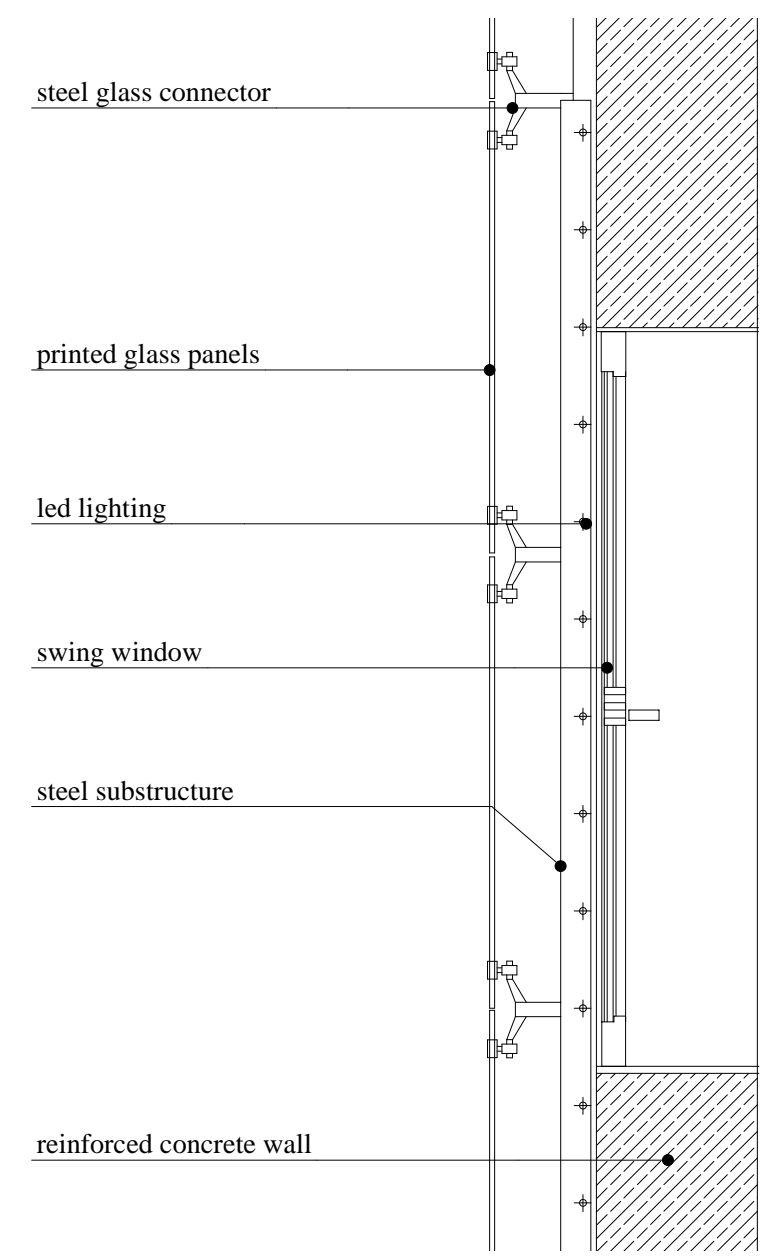

Source: drawing by the Author, based on www.dip-tech.com/images/pdf/)Rockheim_Museum.pdf

Figure 5. Cross section of the glass facade of the superstructure.

\subsection{Kraanspoor Office Building - Amsterdam, The Netherlands}

The interactive technology also accompanied the 
adaptation of the postindustrial port infrastructure in the former NDSM shipyard in Amsterdam. The reinforced concrete track of an overhead crane was built in 1952, but after 30 years of operation its further existence started to be questioned when the shipyard was liquidated in the 1980s and plans emerged to transform the port territory into an office and trade district. A decision to maintain the structure as an important element of the local cultural landscape was made in 1997 and this year started a discussion on the way the structure situated by the IJ river, which divides the southern historical part of the city from its industrial norther part, should be adapted.

The $270 \mathrm{~m}$-long and $8.7 \mathrm{~m}$-wide reinforced concrete structure hovers $13 \mathrm{~m}$ above the water table of the IJ river in the northern part of the city, linked with the centre by means of shuttle ferries. With reference to the plans to create a modern commercial city district, it became an inspiration for an innovative office building erected in 2008, which maintains the full length of the track of the historic overhead crane. At the same time, thanks to its length it creates a closure of the urban axis and yards between the newly erected buildings, demarcating semi-public urban interiors. It also constitutes an attractive envelope of the marina, which after the liquidation of the industrial function was established in the port pool.

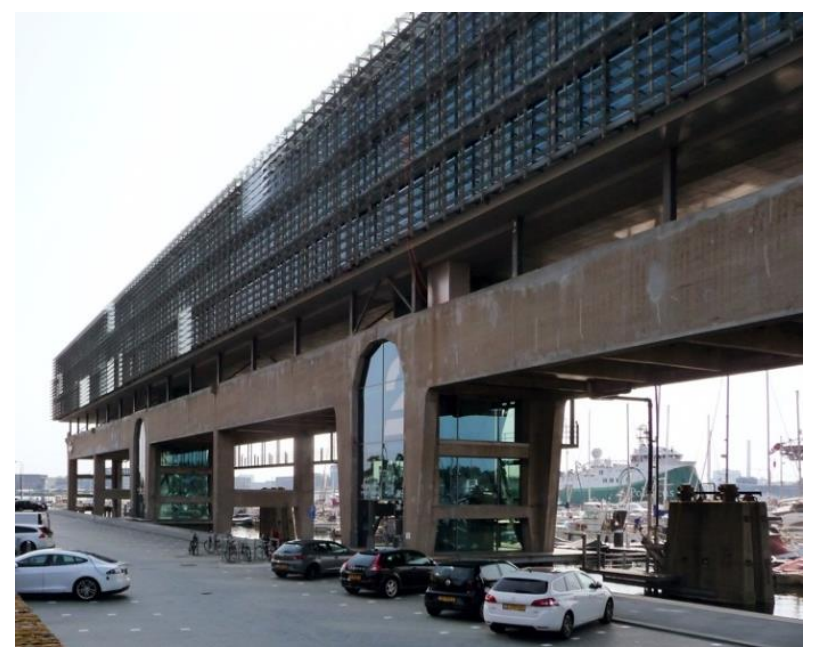

source: photo by the Author

Figure 6. The body of the Kraanspoor office building by the IJ river in Amsterdam, the marina in the background

The main challenge faced by the designers - the OTH studio - was not only to cope with the exceptional length of the building suspended above water, but also to design as much floor surface as possible with the smallest possible load on the existing structure. Consequently, a 3 -floor glass element came into being, measuring $270 \mathrm{~m} \mathrm{x}$ $13.5 \mathrm{~m} \times 10.5 \mathrm{~m}$, which thanks to a network of steel posts supported on a reinforced concrete structure hovers $3 \mathrm{~m}$ above the historical track of the overhead crane of the port (Figure 6). The steel frame structure of the new building and the application of ultra-thin $7 \mathrm{~cm}$-thick ceilings Infra+ allowed to reduce the weight of the designed building nearly twice, thanks to which it was possible to obtain 10 thousand square metres of office space. Additionally, four original staircases located between the reinforced concrete pillars were adapted, creating independent entrances from the level of the waterfront and leading to subsequent office segments [24].

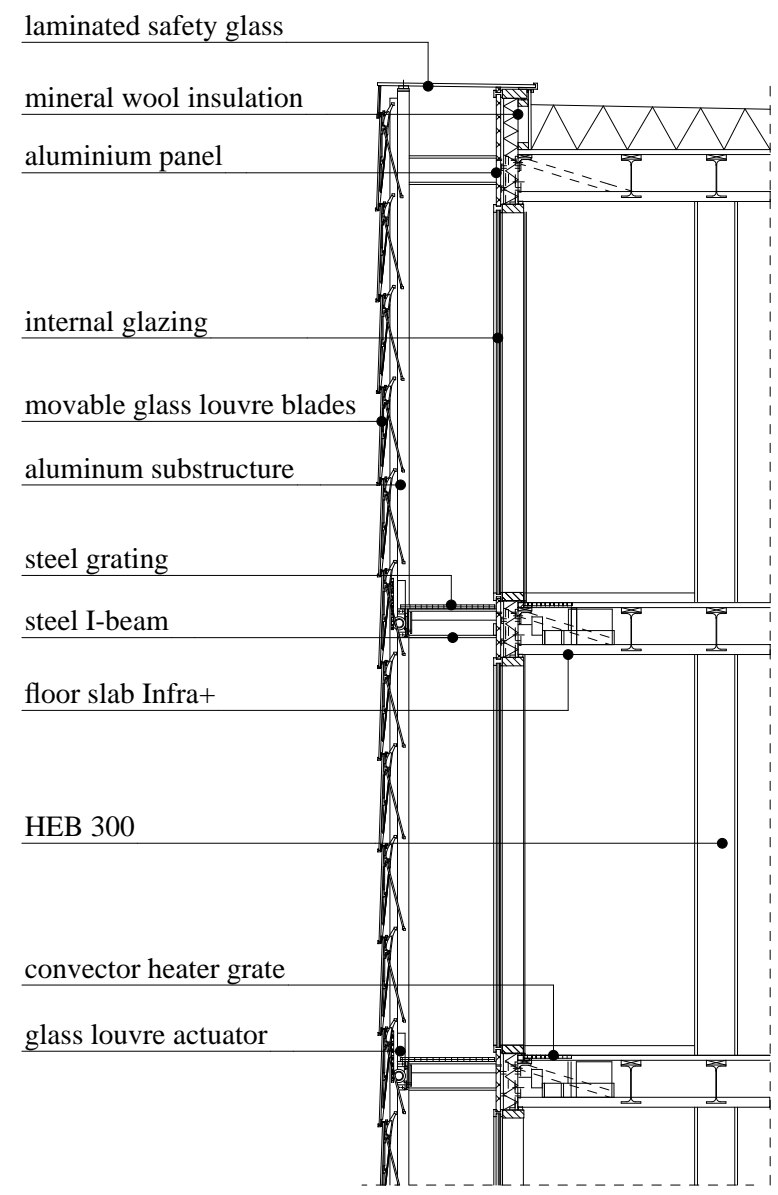

source: drawing by the Author based on [26]

Figure 7. Cross section of the glass façade.

The most interesting element of the simple glass structure is its transparent ventilated segment double-skin façade [20], which thanks to the use of a system of glass blinds GIG Glastec fulfils additional functions regulating the microclimate of the interior and guarantees an excellent view of the landscape surrounding the IJ river. A double glass panel fixed in wooden frames arranged between the ceilings constitutes an internal partition. The outer layer comprises automatically controlled glass lamellas of the blinds, of the total surface area of 6 thousand square metres, embedded in an aluminium substructure. The movable blades open up to the maximum angle of $90^{\circ}$ and are automatically controlled by means of actuators coupled with a weather sensor system (Figure 7). They regulate the illumination level of offices with daylight and they reduce the reflection of 
sunlight from the water. In the closed position they are resistant to weather conditions and they act as a typical buffer zone of a double-skin glass façade, facilitating ventilation of offices and supporting the thermoregulation process inside. Thanks to the application of innovative technologies, but also thanks to the involvement in saving the industrial heritage, the Kraanspoor building has received many awards in the field of sustainable construction, e.g., the Green Building Award MIPIM 2008. However, the greatest merit of the building seems to reside in its contribution to changing of the image of an abandoned district of Amsterdam. The edifice has become a catalyst of changes, which lead to the formation of seeds of a new rapidly developing office and residential district, accumulating innovative companies, and the former port pool has been transformed into the largest marina of the city [25].

\section{Conclusions}

Cultural heritage, including the heritage of the industrial culture, offers enormous possibilities of shaping the contemporary appearance of the cultural landscape of cities. This is fostered by a change in the understanding of the concept of cultural heritage, which has evolved towards its creative use for contemporary purposes, and not only towards the determination of the method of protecting historical values. At the same time, a question emerged at the meeting point of these concept, relating to the interpretation of heritage and the possibility of making use of historical values in favour of the local development. As Prof. Jacek Purchla [11] explains, cultural heritage is "a concept which in recent decades seems to be necessary for understanding the relations between the past and the present". Le Goff, [after: 26] describing the relationship between the social memory and obscurity, claims that contemporary people "are haunted by the fear of memory loss, collective amnesia, which finds it expression in the return to the so-called vintage trend, which is the trend of the past, uncritically used by memory markets, and memory has become one of the symbols in the consumer society". Therefore, is the process of adapting historical industrial buildings for new purposes a result of a ruthless market game and marketing of developers? Or perhaps local communities, which wish to save symbols of the past and elements of their own identity from obscurity, succeeded in emphasising structures which are seemingly worthless, and sometimes even burdensome? As Sanetra-Szeliga and Jagodzińska [27] write, "Heritage is a dynamic concept, something becomes heritage, but something can also cease to be heritage, because it is a result of a choice we make today". A similar approach is presented by Tomaszewski [28], who believes that "Cultural heritage ... is a question of choice and acceptance. It is not everything which past generations handed down to us, but what we wish to accept from it to be our own and which we wish to take responsibility for."

Heritage is understood as a dynamic process taking place in the present, even though it consists of elements deriving from the past, allowing to interpret it and use for further development, but also for learning and understanding the past of a given place. This understanding, which is the key to the appreciation of values of postindustrial buildings and to the preservation of the identity and tradition of cities and regions, can on the one hand lead to the preservation of heritage, which otherwise would not stand a chance of survival, and on the other hand, through creative adaptation for contemporary purposes, it can lead to the creation of a new positive image of degraded postindustrial areas and districts. The examples presented herein illustrate how thanks to a creative approach towards abandoned structures the potential of industrial structures was stirred again, maintaining a dialogue between history and modernity.

Judith Alfrey and Tim Putnam [29] argue that, "If heritage is to belong to people instead of being held out to them or administered for them, then they have to be able to share the moment around which this heritage is integrated, using results that are passed to them by commerce, cultural institutions and state educational authorities. Recognition of this has also been the starting point for much recent work in urban regeneration." Owing to the change in the perception of postindustrial structures, abandoned and degraded postindustrial buildings and installations, although still a spatial problem, became an inspiration for creative use and wide-ranging adaptation measures. When their historical and cultural value got recognised, their rank increased as structures offering considerable possibilities in terms of their reuse. Today many industrial cities and regions willingly involve their potential in the process of building their new, positive image, creating attractive urban spaces with unique architectural values, at the same time remaining in line with the history and tradition of the place. The process of adaptive reuse often applies innovative technological solutions, which allow to adapt historical structures to contemporary requirements in terms of performance and aesthetics. A frequently applied solution is adding glazed structures to the existing buildings, highlighting the monumental appeal of industrial heritage, and at the same time manifesting the latest technical and technological possibilities.

Only 30 years ago, these measures would have been impossible as the conservation doctrine was reluctant to allow such far-reaching transformations in urban spaces exhibiting historical and cultural values. At the same time, thanks to the growing appreciation for industrial heritage, these structures could be preserved for future generations, rather than being liquidated, as it used to be the case before. The change of views on heritage valuation and preservation we have been observing in recent years, an 
interdisciplinary approach from the perspective of sociology, economics, management, and marketing, has offered new possibilities of practical measures, which combined with advanced construction technologies have produced excellent results. These results are associated with transformations in the architectural scale, creating space for new functions and activities, but also in the urban scale - the scale of degraded city districts, which now have become important parts of public spaces in towns and cities.

Heike Oevermann and Harald Mieg [30] observe that: "For urban development, conscientious authenticity and integrity of the structural fabric are not important; what matters is the transformation from a former industrial site into a place with prospects for the future... Generally, the design is not based on an analysis of historical significance but, instead, the existing structure is understood as raw material that inspires interpretations and transformations. But spatial quality is of importance. Iconic architecture serves as flagship projects, intended to advance economic development." These measures need to be carefully considered, because it is paramount to maintain a balance with an acceptable degree of changes in the historical urban tissue [31]. Too far-reaching obliteration / destruction of elements of the identity of place may prevent local development based on a unique cultural capital [32].

\section{REFERENCES}

[1] N. Juzwa, A. Gil, A. Sulimowska, A. Witeczek. Architecture and Urban Planning for Contemporary Industry, Wydawnictwo Politechniki Śląskiej, Gliwice, 2016.

[2] N. Cossons. Why preserve the industrial heritage? Industrial Heritage Re-tooled: The TICCIH guide to Industrial Heritage Conservation, 6-16, TICCIH, Carnegie House, Lancaster, 2012.

[3] M. Oglethorpe. Industrial heritage: realising the value of our historic assets, Central Europe towards Sustainable Building, Prague, 2013

[4] R. Florida. Cities and the Creative Class, New York London, 2005.

[5] K. Kowalski. O istocie dziedzictwa europejskiego rozważania, Międzynarodowe Centrum Kultury, Kraków, 2013.

[6] J. Tunbridge, Zmiana warty. Dziedzictwo na przełomie XX i XXI wieku, Międzynarodowe Centrum Kultury, Kraków, 2018.

[7] P. Nora. Between Memory and History: Les Lieux De Mémoire, Representations, no. 26, 7-24, 1989.

[8] G. Ashworth, Planowanie dziedzictwa, Międzynarodowe Centrum Kultury, Kraków, 2015.
[9] R. Towse. A Textbook of Cultural Economics, Cambridge University Press, Cambridge 2010

[10] D. Thorsby. Economic and Culture, Cambridge University Press, Cambridge 2001

[11] J. Purchla. Dziedzictwo kulturowe. Kultura a rozwój. NCK, Warszawa, 2013.

[12] M. Kupisz-Murzyn. Dziedzictwo kulturowe a rozwój lokalny, Wydawnictwo Uniwesytetu Ekonomicznego w Krakowie, Kraków 2012

[13] W. Affelt. Technitas. Konteksty dziedzictwa kulturowego techniki, Muzeum Górnictwa Węglowego, Zabrze 2015.

[14] S. Januszewski. Archeologia przemysłowa - jej narodziny i przedmiot badań, Spotkania z Zabytkami Vol 34, No 3/4, 6-15, 2010.

[15] The Nizhny Tagil Charter for the Industrial Heritage, Online available from http://ticcih.org/ about/charter/

[16] R. Ryce-Paul. Waterfront revitalisation profitability vs social equity strategies shaping the urban waterfront, Master Thesis Columbia University, 2004

[17] K. Karatzias, K. Lindqvist. Attractiveness through mystique. The Case of the Culture Yard, Helsingør, Denmark. Managing Organisational Success in the Arts, Routledge, 2019

[18] C. Mordhorst. Strategic management in a local and global perpective. Museums, Knowledge, Democracy, Transformation. Helsing ør, Styrelsen. Danish Agency for Culture, 224-237, 2014

[19] Zeitz Museum of Contemporary Art Africa (MOCAA), Concrete Beton, No 150, 8, 2017.

[20] E. Wala. Szkło we współczesnej architekturze. Wydawnictwo Politechniki Śląskej, Gliwice, 2017.

[21] K. Zyczkowska. Uniqueness or Uniformity - Studies of Media Architecture, IOP Conf. Ser.: Mater. Sci. Eng. 471 072040, 2019

[22] Rockheim, Trondheim. Online available from http://www.architecturenorway.no/projects/culture/rockhei $\mathrm{m}-2010 /$

[23] Rockheim Museum Project. Online available from https://www.glassglobal.com/news/rockheim-museum-proj ect-18424.html

[24] Kraanspoor Office Building in Amsterdam. Online available from

https://www.detail-online.com/article/kraanspoor-office-bui lding-in-amsterdam-14564/

[25] Kraanspoor / OTH Architecten. Online available from https://www.archdaily.com/2967/kraanspoor-oth-ontwerpgr oep-trude-hooykaas-bv

[26] S. Di Resta. Modernity And Oblivion: Adaptive Reuse And Collective memories In Heritage Conservation Experiences, Conservation Adaptation - Keeping Alive The Spirit Of The Place Adaptive Reuse Of Heritage With Symbolic Value, European Association for Architectural Education, Belgium 2017 
[27] J. Sanetra-Szeliga, K. Jagodzińska. Społeczno-ekonomiczny wpływ dziedzictwa kulturowego. Aspekty teoretyczne, Potencjał dziedzictwa, Międzynarodowe Centrum Kultury, Kraków 2017.

[28] A. Tomaszewski. Ku nowej filozofii dziedzictwa, Międzynarodowe Centrum Kultury, Kraków, 2012.

[29] J. Alfrey, T. Putnam. The Industrial Heritage. Managing resources and uses. Routledge, London 1992
[30] H. Oevermann, H. A. Mieg, Exploring urban transformations: Synchronic discourse analysis in the field of heritage conservation and urban development, Journal of Urban Regeneration and Renewal Vol. 9, 1, 54-64, 2015

[31] G. Licciardi, R. Amirtahmasebi. The Economics of Uniqueness: Historic Cities and Cultural Heritage Assets as Public Goods. Washington DC, 2012.

[32] D. Throsby. Cultural capital, Journal of Cultural Economics, no. 23, 3-12, 1999 